The International Journal Of Engineering And Science (IJES)

|| Volume || 6 || Issue || 1 || Pages || PP 08-12 || 2017 ||

ISSN (e): $2319-1813$ ISSN (p): $2319-1805$

\title{
Vietnam Theological Epitaph
}

\author{
Nguyen Van Hai ${ }^{1}$, Zai Hua Liu ${ }^{2}$ \\ ${ }^{l}$ PhD Student at College of Chinese language and literature - Hunan University, China. \\ ${ }^{2}$ Professor at College of Chinese language and literature - Hunan University, China.
}

\begin{abstract}
The holy epitaph in Vietnam written in Han Chinese language that orginated in China is erected in the southeast of the royal tomb of emperors, royal relatives and high-ranking officials. The epitaph was usually written by contemporary famous writers, thus the literature was modest and the historical material was enormous. This article would show some remarks of the history of the holy epitaph and introduce the value of the holy epitaph on aspects of literature, history, culture and education.
\end{abstract}

Keywords: Theology, theological epitaph, name of a reign's years, writer, functionary, position, year of establishment, value, princess, prince consort

Date of Submission: 16 January 2017

$\longrightarrow$

Date of Accepted: 01 February 2017

\section{OVERVIEW}

Of the treasure of the Vietnamese epitaph written in the Chinese language, the holy epitaph made up a quitesmall proportion. The content consists primarily of cultural and social life, describing world outlook and human life in various historical periods. The article is going to explain the contents of particular epitaphs and would help people understand some aspects of contemporary cultural-social life.

\section{ORIGIN OF THEOLOGICAL EPITAPH}

As a category within the system of gravestones, the theological epitaph considers the praise of great contribution of the deceased as a main aspect, therefore, it has received special respect from officials. In terms of origin, the theological epitaph was launched at the request of funeral regimes at the ancient times, originating from China. From the immemorial time, according to the feng shui experts, the Southeast of the tomb was considered as a theological direction, therefore, establishing an theological epitaph in the Southeastern was called as the "theology" (1). At the beginning of the Ming dynasty, the regulation of the establishment of the holy epitaph was maintained as the Duong dynasty, that is, officials with five-levels or higher ranking would be able to be built for the holy epitaph when they passed away. Futhermore, the dragon designs on the forehead and pedestal of the stone turtle were regulated more clearly. From that time, the theological epitaph became a genre specialising for the upper class of feudal society.

In China, the theological epitaph was launched from the reign of Dong Han, Han Hoa De and in the first year of Hung Nguyen's time (105).( ${ }^{(2)}$, but at the Duong dynasty, officials at the five levels or higher were provided with the theological epitaphs ${ }^{(3)}$ and at the Minh dynasty, officials at the three levels or higher were provided with the theological epitaphs. In Vietnam, establishing the theological epitaph was applied under the regulations of China, therefore, it was applied for the officials with high positions in the society. The theological epitaph has had the same structures as other epitaphs, its traditional structure is divided into 3 parts: title (name of the epitaph), an then "chi" or "ky" and finally "minh". In some epitaphs, there is "chi" or "ky" but not "minh" in the front or "chi" or "ky" and "minh" but not "title". This epitaph is special and rare.

\section{DEVELOPMENT HISTORY OF THE THEOLOGICAL EPITAPH}

In Vietnam, the theological epitaph of Ly-Tran period have found just only one called "Phung Duong cong chua than dao bi minh tinh tu" (the title and the "minh" were carved on the epitaph "Phung Duong princess"). It was found in Doc Lap hamlet, My Loc district, Thien Truong residence ( My Thanh village, My Loc district, Nam Dinh province, the present time) and composed by Le Cung Vien. The epitaph was carved the reign of Trung Hung VIII (1293), Tran Nhan Tong's time and it was the first epitaph discovered in the system of the Vietnamese holy epitaph in the Ly-Tran period. Apparently, the holy epitaph not only comprised the birth and dead years but also extolled dedications.

Le So's reign (1427-1528): the number of theological epitaphs increased, but all of them were concentrated in the province of Thanh Hoa where originally rose up Lam Son revolt. Statistically, there were 6 officially theological epitaphs nationwide in this period. In addition, there were also 6 epitaphs established in the 
southeast of Le So kings and queens' tombs at the historic monument of Lam Kinh, Tho Xuan district, Thanh Hoa province, considered as the theological genre by scholars. The epitaph of this period was categorized into 2 groups: one wrote about kings, queens, royal concubines, princes, princesses who were royal relatives of the King; the other group belonged to meritorious officials who had rendered outstanding service.

Le Trung Hung's reign: During the civil war, there were many meritorious officials who contributed extraodinary service and assisted their own leaders. In such a situation, it could be assumed that the holy epitaph type would have developed dramatically but in fact, the opposite was true. Historically, 60 years of the civil war between Le-Trinh and Mac dynasties and 160 years of the Trinh-Nguyen conflict caused the destruction of social-economical foundation. The people were miserable, poor and hard. The rewards for officials were also limited, therefore the construction of epitaphs and tombs was affected negatively. We have found just 5 and 1 epitaphs of Le Trung Hung and Mac's reigns, respectively, in this period of Vietnamese history.

Tay Son time period (1779-1802): Nguyen Hue brothers helped ending the division between South-North Vietnam, unifying the nation but this reign existed just 23 years. Additionally, as soon as Nguyen Anh was crowned king and established Nguyen's reign (1802-1945), he decided to seek and destroy all of the documents relating with Tay Son's reign. As a result, no theological epitaphs in this period have been found until now.

Nguyen dynasty (1802-1945): Thanks to the support of foreigners, Nguyen Anh established Nguyen' reign in 1802 and recorded great achievements in various fields, especially applying many policies to reinforce the system of confucianism, strengthen education, improve human behaviours, centralise knowledge, enhance human personality. The contemporary holy epitaphs were not compiled by not only well-known writers but also disciples who were outstanding notables. Because expecting favours from above, they offered helps. Now, we have collected 9 theological epitaphs of this period, distributed all over the country.

\section{DOCUMENTARY VALUES OF THE THEOLOGICAL EPITAPHS}

The theological epitaphs have been mostly compiled by the talented persons and famous writers, mentioning the history of the deceased including: regeneration, family, full name, title, posiiton, age, date of dead and place of tomb; therfore, it has been considered as epitaph applying and maintaining many of precious materials on talented persons and gained the history and literature aspects. Through the recorded materials, we can gain good understanding for many fields:

\section{1.Literature aspect:}

As can be seen clearly, holy epitaphs are very rich in literature, many of them are extraodinary, especially when writing the biography of the deceased, the writer use particular details to portray the character, clarifying talents and characteristics that is vivid lively. In short, they are really holy life stories, extremely attractive. In fact, the majority of Vietnamese theorilogical epitaphs were always written by intelligentsias who are outstanding writers such as Nguyen Trai, Nguyen Truc, Luong The Vinh, Than Nhan Trung, Nguyen Thien Tich, Dam Van Le, Luu Hung Hieu, Nguyen Nghiem, Nguyen Van Sieu. Epitaph posts are lively specific writings about lifes of emperors, kings and queens, famous officials and generals. They not only have connected and clear lay-outs, abridged writing and proper classic reference but also are rich in affection and deep in literature quality. For example, "Lam Son Vinh Lang bi"' is the epitaph of Le Thai To's tomb, mostly described the process of building up the King's fortune. As the ancients estimated, it was an excellent work inparalell prose. Pham Dinh Ho commented " Its spirituality could follow the path of the men of old '. This writing took the tell a story as central but the style was self-willing and passionately deep. The words objectively focused on describing the personality of the King through his art of fighting and was not diffuse, but appeared an image of a robust and confident King that full of attractive. This style of writing is so colorful, absolutely outweighing the "so-called" firm tell a story type.

'Tho An cung kinh phi Nguyen thi than dao"' is an outstanding epitaph post about the life of Nguyen Thi kinhphi. The writing was to sing the praise of her righteousness and good character towards thinking high of worshiping the king, also devolting deep love for bringing up the princes and princesses. She was keen on reading books, had a good sense of reason, clearly expressed righteousness, good character and standards of Vietnamese women personality. The sentences and words were so special as though telling endless reminiscences, making readers feel out truthfulness, friendliness and full of life atmosphere and affection.

\subsection{Contribution for good understanding on family history of characters:}

Beside recording life stories, the epitaph also mentioned merits of characters who contributed to the history of building and defending the country. The epitaph "Than Dao bi, not only writing down the family history of Thai te Vinh Quoc cong Hoang Dinh Ai, it also contains details about historical events ( date, month, year) and places in association with the battles between Hoang Dinh Thai and Mac's armies: beginning from the time Hoang Dinh Ai devolted himself for supporting Minh Khang Thai Vuong (Trinh Kiem), experienced 22 various battles and the materials recording Hoang Dinh Thai's merits of recruiting soldiers, welcoming the foreign 
ambassador. This epitaph could be seen as a stone historical page, recording the task of quelling Mac dynasty, restoring Le dynasty in a detailed way. Also thanks to the content of the epitaph, the writing help us redefine the author who compiled this epitaph, that is PhD Ngo Tri Hoa, it was not of Ta thi lang bo le Nguyen Le ( the book Dai Viet Su ki toan thu va Lich trieu hien chuong loai chi had recorded). Through the content of the epitaph "Tho an cung kinh phi Nguyen thi than dao bi", we could know that in the Le So time there were 2 Kinh phi with the first name of Nguyen. They both were the King's royal concubines, and had merits of bringing up the prince. One came from Bat Cang village, Loi Duong district ( Tho Nguyen village, Tho Xuan district, Thanh Hoa province in the present time). She was the royal concubine of Le Thanh Tong King and was burried in Tam $\mathrm{Lu}$ area, Loi Duong district after deceased. The other Kinh phi Nguyen Thi is the concubines of the king of Le Hien Tong, originated from Hoa Lang village, Loi Duong district Hai Phong province. Based on this information, to reverify the tomb of Kinh phi Nguyen thi at Tam Lu village, Loi Duong district who is the concubine of King Le Thanh Tong, not as locally historical books recorded that she was the concubine of King Le Hien Tong.

\subsection{Contribution for good understanding on contributions of characters:}

This is a concentrated field which all theological epitaphs mentioned. It can be said, the theological epitaph is considered as a great story, through interesting sentences of the authors, the whole life the character was described clearly to help the readers imagine their contributions and typical characteristics. For the epitaphs on royal concubines, princes and princesses, they were talented and friendly with everyone. The epitaph "Phung Duong cong chua than dao bi" helped us understand that the princess was intelligent and polite since she was small, but when Tran Quang Khai got married to another wife and did not behave her greatly, she still suffered, even though her parents advised her but she still kept principles of a good wife and was polite with everyone and cared for her husband when he was ill. The epitaph "Tho An cung Kinh phi Nguyen thi than dao bi" mentioned that Kinh Phi in surname of Nguyen was polite, scareful and modest and did not express any thing when she was sad and she did not complain anyone, therefore, the king loved her very much and she was assigned to nourish the $8^{\text {th }}$ prince as her son. The epitaph "Cam Vinh Chuong cong chua than dao bi" mentioned that when the princess was small, she was polite and friendly and received great love from the king...etc. For the epitaphs mentioning the characters, they are considered as valuable rock history pages, mentioning activities of the talented persons in each period of history. Therefore, through them, we can gain additional understanding on great contributions of the characters in many fields and previous materials for history research as: the epitaph "Khai quoc cong than Thai su Dinh Quoc cong Do Dai bi", in addition to detailed information on information of Do Khuyen in 3 king reigns, we can gain additional researches of roles of the officials and country organization and development in the Le So dynasty. The epitaph "Binh ngo khai quoc cong than Thai uy Trinh quoc cong than bao bi", through detailed information on contributions of the character, we can gain additional understanding on position and contributions of Nguyen Duc Trung into the large history sets such as "Dai Viet su ky toan thu" and "Kham dinh Viet su thong giam cuong muc" from the first year of Quang Thuan $(1460)^{(4)}$. For mentioning the contributions of the characters, the epitaph "than dao bi ky", in addition to recording on the contributions of Hoang Dinh Ai, position Thai Te, title Vinh Quoc cong, we can determine the compiling author, Dr Ngo Tri Hoa but not Ta Thi lang in Le Nguyen Le reign, as mentioned in the large history sets. ${ }^{(5)}$

4.4. For education: This is mentioned in the theological epitaph, we can understand in any period of the feudal era, education received special attention from the country, for example, the country opened many schools and private schools of talented persons were opened : The epitaph «Phuong Dinh chi dao tien sinh than dao bi », in the introduction, it mentioned that the talented persons could be officials and help the king and the public and after resigning, they could teach and train other talent persons. Therefore, Nguyen Van Sieu after resigning established a school at Giang Nguyen, 30 his students were officals with high positions in the reign such as : Han Lam vien Thi doc Nguyen Khac Chuoc, An Sat su Hai Duong Nguyen Giap, Hiep bien Dai hoc si and leader of Vinh Xuong Tran Luu Tue, Thi Giang hoc si, An sat su Hai Duong Trinh Tien Sinh..

4.5. For friendship, respect and admiration: Normally, before establishing, each theological epitaph had various reasons, the epitaphs were compiled for friendship or officials in the same dynasty, somes reflected respect between teachers and students, others reflected admiration of the later generations for the previous generations. All reflected great moral trandition of Vietnamses in many fields in the theological epitaphs. For examples, the epitaph «Phuong Dinh chi dao tien sinh than dao bi » mentioned that teacher Nguyen Van Sieu died, after 20 yers, his students wanted to compile an epitaph to clarify his academic history and characteristics. The epitaph also mentiioned expressions of Dr Nguyen Trong Hop, an official in the same reign, the same hometown and the same surname as Nguyen Van Sieu, he thought that he was foolish and did not mentioned all contributions, therefore, he did not do this, because students kindly asked him to do this, he could not refuse. The epitaph «Le Hoang Nhan Trai tien sinh than dao bi » mentioned that Mr Le Hoang Banh (also known Dinh Giao) passed in the Huong exam, and awarded by the king but he did not receive, because of his old mother, he taught and became a famous teacher in the reign. After he died, more than 100 students attended to his funeral 
and compiled an epitaph to mention his contributions. For also mentioning this topic, the epitaph «Tran tien si mo than dao bi » mentioned that when Dr Tran Troi died, his son and students wanted to establish an theological epitaph to mentioend his contributions. At that time, nguye Huy Sang as leader of Quoc Oai, a friend in the same hometown, the same period and admiration for him, compiled the epitaph...

4.6.Culture, customs and tradition: This issue was mentioned in some epitaphs, reflecting some characters in the heart of the public and their contributions for the community, when they died, they were interred in the tempers by the king. Some had great contributions for the hometown, when they died, the public established the epitaphs mentioning worshiping tradition and honored as talented persons of the villages. The epitaphs «tan tao tiet nghia than dao bia», after he died within 100 years, his epitaph was established mentioning his contributuons in the Le So reign and the entire convention of the public and the worshiping traddition for him. The epitaph «Gia lam huyen, Lac Dao xa phung su Thuong thu Duong cong than dao bi » mentioned conttributions of Duong Cong Thu to the public, when he died, they established his epitaph and allocated their land to gain costs for his woshiping. For this issue, the epitaph, "Phuong Dinh chi than dao bi " mentioned that father of Nguyen Van Sieu moved to Giang Nguyen, Tho Xuong district and lived there. Nguyen Van Sieu wanted to remember his previous generation's condibutions, he established the epitaph in this village. In each year, at the Dong Chi date, the public attended this occasion and the public established a temper in To Lich river; the king awarded for the public with the second flag to worship Doctor in the Tran dynasty, Nguyen Trung Ngan.

\section{CONCLUSION}

It can be said, documentary values were mentioned in many theological epitaphs, we only offer basic values on the materials which the theological epitaphs mentioned, in many other fields such as fighting against the colonialists to keep the territory, prevention of rampant persons to protect security to the public or embankment for dikes to protect crops, re-determination of taxes to bring benefits for the public, enriching the country... These fields were attached to contributions of many characters, it is necessary to research each epitaph. It is hoped that this article can help the readers and researchers understand the theological epitaphs as well as their documentary values for researching Vietnam history in the feudalism.

\section{Notes}

1. Phong Dien "Phong Thuy van kien ki" ("Bi Kiet", Vu Duong article (old Kanji).

2. The epitaph was discovered in June, 1964 at Dong Thong Trang in Tay Giao Thach Canh Son and maintained at Van Vat Cong Tac Doi - Beijing. It is maintained at Bach Thap Thu Bach Khac museum Beijing. The epitaph is mentioned in "Chinese Culture" written by Kim Ky Trinh, Trung Khanh Publishing Housing, 2001, page 86 (modern kanji).

3. Extrached from "Comparison on research of Han Du and Au Duong Tu", Master thesis of Do Le Binh, NorthEast Education University (China), 2005. (Modern kanji), page 4. We found writings on the book Mingshi, 36juan, (Lễ 40). (Ming History, Volume 36; Lễ 40)

4. Through the contents of the epitaph, we find that Nguyen Duc Trung pursued Le Loi from year of Lam Son revolution. But as mentioned in Dai Viet su ky toan thu and Kham dinh Viet su thong giam cuong muc, his name was only mentioned after the first year of Quang Thuan (1460), because he together with Dinh Liet and Nguyen Xi dismissed Nghi Dan and took Thanh Tong king to become a king, at that time, he was Dien tien do.

5. According to the practical survey, and the documents of the epitaph: the genealogy books of Hoang family at Vinh Hung commune, Vinh Loc district; documents are stored at Han Nom research institure in Hanoi: Vinh loc huyen chi, Vinh Loc phong tho chi, Thanh Hoa tinh Vinh Loc huyen chien. They are translated by Nguyen Van Hai, Thanh Hoa publishing housing 2010, the first edition in 2012. The epitaph as mentioned in the books are uniform for the author Dr Ngo Tri Hoa but not Nguyen Le. We will offer a separate article for this field.

\section{REFERENCES}

[1]. Vietnam Social Science Institute (1993) "Đại Việt Sử ký toàn thư” (Full letter Great Vietnamese history) , Hanoi Social Science Publishing Housing.

[2]. Phan Huy Chu (1960) "Lịch triều Hiến chương loại chí" History Publishing House.

[3]. Luu Cong Dao (1816) Vinh loc Huyen chi, code VHv.1371 / AB. (Kanji version). Vinh Loc Phong tho chi code A.2537 (kanji version). Thanh hoa tinh Vinh Loc huyen chi, code VHv.137 / AB (kanji version).

[4]. Trinh Khac Manh. (2013) "Bi Ký học và văn bản bi ký Hán Nôm Việt nam" Social Science Publishing Housing

[5]. Trinh Khac Manh (2008) " Một số vấn đề về văn bia Việt Nam "(Some problems of Vietnam epitaph ) Social Sciences Publishing House.

[6]. "Thanh Hóa tỉnh Vĩnh Lộc huyện chí "Translator Nguyen Van Hai, Thanh Hoa Publishing Housing, 2010, 1st edition, 2012.

[7]. Editor Ngo Quang Hong, (2006), "Tuyển tập Văn khắc Hán Nôm Việt Nam." (Volume of Vietnam Han Nom engraved Literature) Social Science Publishing Housing 1992. 
[8]. Nguyen Van Hai - Le Toan (2014) " Tuyển tập văn bia Thanh Hóa - Văn bia triều Lê sơ" (Volume of Thanh Hoa epitaph - epitaph at the Le So reign) volume 2, Thanh Hoa Publishing Housing

[9]. The Board of Research and Editing of Thanh Hoa History (2006) "Danh nhân Thanh Hóa" (Thanh Hoa Celebrities). Thanh Hoa Publishing Housing.

[10]. $\quad 10$ The Board of Research and Editing of Thanh Hoa History (2001) "Tên làng xã Thanh Hóa" (name of Thanh Hoa communes and villages), volume 1, volume 2, Thanh Hoa Publishing Housing.

[11]. "Thơ Văn Lý Trần" (Ly Tran Literature and Poems) Social Science Housing Housing 1977 - volume II

[12]. Tran Van Thinh (1995) "Danh sĩ Thanh Hóa và việc học thời xưa" (Thanh Hoa talented persons and previous education) Thanh Hoa Publishing Housing.

[13]. " Lược chuyện các tác gia Việt Nam "History story of Vietnam authors, volume 1, Social Science Housing Housing - Hanoi, Edition 1971

[14]. " Phan húy chú và dòng họ Phan Huy " (Phan Huy Chu and Phan Huy family), Ha Son Binh Department of Culture and Communications, 1938

[15]. Kim Ky Trinh (2001) "zhongguo bei wenhua" zhongqing chuban she (Trung Quoc Bi van hoa) Trung Khanh xuat ban xa (modern Kanji version)

[16]. Phong Dien"fengshui wen jian ji" (Phong thuy van kien ki "Bi Kiet") Vu Duong tang ban ( old kanji) 